Skrywer: Bettina Wyngaardt

Titel: $\quad$ Slaafs

Uitgewer: Umuzi

Jaartal: 2016

Bladsye: 292

Prys: $\quad$ R206.00

\title{
Slaafs - 'n verhaal van menslike handel
}

Die skrywer van Troos vir die gebrokenes (wenner van die Jan Rabie

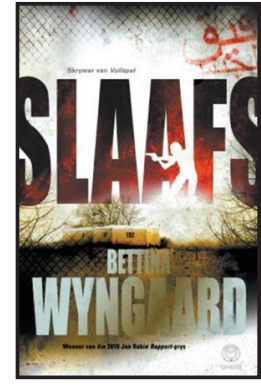
Rapport-prys) en die misdaadroman Vuilspel raak in hierdie werk - haar tweede misdaadroman - 'n paar baie belangrike temas aan, sommige nog nie vantevore deur enige ander skrywer aangedurf nie.

Soos Deon Meyer bekendheid verwerf het met sy misdaadromans met baaspeurder Bennie Griesel, so is Wyngaardt besig om 'n nuwe baasspeurder as 'n huishoudelike naam in die SuidAfrikaanse letterkunde te vestig; die verskil is dat Wyngaardt 'n vroulike baasspeurder gebruik om die onderwêreld te infiltreer. Kaptein Nicci de Wee, of "ounooi" soos haar kollega en boesemvriend Blackie Swart haar noem, werk in die polisiestasie van Kayalitsha, 'n terrein waar menige man dit nooit sal waag nie, laat staan nog om daar te werk.

In Slaafs val die fokus op daardie vroulike slagoffers wat so sonder naam op die staatspatoloog se outopsietafel beland. En terwyl die pataloë se mediese kennis weinig antwoorde bring, probeer kaptein Nicci die raaiselagtige moorde vanuit 'n polisiestasie in een van die misdadigste woonbuurte op die Kaapse Vlakte ontleed. Maar Wyngaardt betree nog 'n nuwe terrein waar sy baanbrekerswerk doen: die heldin in hierdie spanningsvolle verhaal, is betrokke in 'n gayverhouding met 'n ewe beginselvaste en indrukwekkende priestervriendin: Sally.

Op 'n vreemde dog geloofwaardige wyse vul die speurder en die priester mekaar aan, is hulle eintlik perfekte sielsgenote vir mekaar. Nicci soek haar antwoorde deur die lens van 'n policefile. Sally benader die probleem vanuit 'n religieuse oogpunt en probeer sin maak van die sinlose moorde deur die samelewing in terme van die alomteenwoordige God te verklaar. En dis juis die feit dat hulle met dieselfde probleme worstel - weliswaar vanuit verskillende perpektiewe - wat diepte aan hul verhouding gee.

Ironies genoeg is hul eerste stryery oor 'n man, as dit vir Sally lyk asof Nicci meer vir Blackie omgee as wat sy wil erken (75). Blackie was die eerste van haar kollegas met wie sy openlik oor haar seksualiteit gepraat het (29). Dis nie altyd maklik in hierdie land nie. Sy weet nie hoe ander mense sal reageer op haar gay-status nie. Sommige mense se leefwêreld is klein (20).

Die deernis en liefdevolheid waarmee die skryfster die uiters sensitiewe onderwerp hanteer, maak die verhouding en dus ook die verhaal nie net geloofwaardig nie, dit is vir hierdie leser ook 'n aanduiding dat die skywer baie naby aan 'n gay-paartjie beweeg het. Nooit voel die leser dat ' $n$ bepaalde lewensuitkyk aan jou opgedwing word nie.

Wyngaardt hanteer ook 'n derde belangrike tema: die universele tendens van mensehandel in die volksmond bekend as human trafficking. Sy hanteer die uiters omstrede onderwerp met soveel kundigheid, dat dit vir die ingeligte leser baie gou duidelik word dat sy haar huiswerk deeglik gedoen het. Sy praat met 'n mate van gesag hoe jong meisies onder valse voorwendsels van hul ouerhuise weggelok word om as seksslawe (85) in ander lande verkoop te word. In die proses maak sy vriende met Gigi, 'n feminis wat haar beywer vir 'n organisasie Freedom from Tracfficking Now (FFTN). Hulle help vroue en kinders wat die slagoffers van mensehandel is, om 'n nuwe lewe in Suid-Afrika te begin (34) en deel gereeld pamflette oor mensehandel uit (45). 
Soos in haar vorige romans, maak Wyngaardt ook weer 'n broodnodige bydrae op die gebied van die taal en die woordeskat. In die alledaagse lewe van 'n polisievrou word hulle Afrikaanse woordeskat met Engelse woorde gegeur - byna soos 'n vrou se parfuum. Maar anders as in so baie ander werke (gedrukte en elektroniese media) kry die leser nooit die gevoel dat die skywer Engels aan die Afrikaanse leser wil opdwing nie. Die gebruik van Engels is so spontaan en normaal dat die meeste lesers dit nie eens sal agterkom nie, dalk juis omdat Wyngaardt so na aan die moderne dialek van Afrikaanssprekendes beweeg. Hiervan is daar talle voorbeelde waarvan ek slegs enkeles aanhaal:

Ek het gedink dis sommer straightforward (27); die patoloog hanteer die saak dikwels verkeerdelik as accidental overdose; dikwels word die slagoffer net gedump (Kaapse Afrikaans) in 'n druggie hang out (30); 'n groot deel van Gigi se werk is advocay rondom trafficking (35); Gigi het Blackie provoke (74); Sy is eintlik heel oraait as sy net wil relax (78); Ek is jammer Babes (79); Great! Dan hoef ek nie al die pad te stap nie (81); die meisies kry obviously nie geld vir hulle werk nie (85); Kan jy enigiets wys word uit die paper trail?(267); Okay, ek sal probeer (268); Nicci is 'n meisiekind met guts (270) en Gys lê in die ICU (171).

Die leser sal saamstem dat nie een enkele term vir die moderne Suid-Afrikaner vreemd is nie. Die skryfster het hierdie tegniek tot 'n fyn kuns bemeester -iets wat min ander haar nog kon nadoen.

Ook die taal van die wêreld van die slawesindikaat hanteer Wyngaardt met gesag en outentieke aanslag wat die leser opnuut laat voel dat sy weet waarvan sy praat bv.: "Dis die Heckler en Koch MP5. Die magasyn kan veertig rondes vat"(284).

Sy gebruik met gemak die woord "boks" soos in 'n boks vol dokumente - iets wat ons almal wil doen maar ons word deur die een of ander taalreël gedwing om die woord "doos" te gebruik. Verdere bewys dat sy deeglike navorsing gedoen het, is:

"Met die regte toerusting kan die beeld verhelder, dikwels word video's met 'n goedkoper selfoon geskiet en die pixels van die foon is nie dieselfde as dié van die kamera van 'n smartphone nie; iets wat jy sommer by die Comms-agentskap kan leen...(50)".

Die gedetailleerde beskrywing van die polisiekantoor en sy ameublement (kyk bl.51) en ook die absolute presisie waarmee sy beskryf hoe die polisie 'n kar wat hulle agtervolg, afskud (176), is ' $n$ aanduiding dat die skryfster lang ure in 'n polisiekantoor gespandeer en fyn waargeneem het.

Daar is oulike vars uitdrukkings waarmee sy die leser vergas soos haar beskrywing van 'n selfoon: "Die knoppiedrukkery doen nie die ding vir my nie" (60). Ook: "Vrouens en kinders word onder ons neuse verkoop soos meubelstukke" (63). Maar alles is darem nie net goed nie: soms maak die skryfster gebruik van 'n paar clichés: “Hy is so opgewonde soos 'n kind met 'n nuwe speelding" (53) en "Hy is oud en lelik genoeg om dit self te doen" (77).

Wyngaardt skryf goed, baie goed, maar sy is ook maar net mens.

Die verhaal skets die bedrywighede van 'n slawesindikaat en beklemtoon opnuut dat die skurke van hierdie duistere wêreld hulself soos gentlemen vermom. Dit is juis hierdie goedversorgde, besgeklede mans met hul gladde bekke waarvoor ouers moet uitkyk, want dis hulle wat onskuldige dogters herhaaldelik verkrag en so aan die onderwêreld bekendstel (275).

Dis 'n wêreld waar die enigste taal dié is van Amerikaanse dollars; waar wagte omgekoop word (275). Dikwels skuil daar baie meer agter 'n "dood weens 'n ooglopende oordosis pille" (28). Tekens waarvoor uitgekyk moet word, is meisies met seksueel oordraagbare siektes, aborsies, en 'n brandmerk (45) in die vorm van 'n ketting-en-roos-tattoe (46). Die meisies praat dikwels nie Engels nie, en word gereeld na 'n kliniek in Groenpunt in die Kaap gebring. Meestal 
word hulle vergesel van 'n ouer man (vergelyk bv. die verhaal van Baby deur EKM Dido).

Die meisies is almal verslaaf aan dwelms en moet hulself gereeld met heroïen inspuit want dis 'n manier om hulle beheerbaar en afhanklik te maak van die slawebaas (279). Om te verhoed dat hulle die omgewing leer ken, word hulle geblinddoek as hulle vervoer word (280). Die meeste eindig in 'n vlak graf êrens in die bosse. Diegene wat so gelukkig is om aan hierdie hel te ontsnap, se wonde aan hul liggaam mag dalk genees, maar daar is ander wonde wat baie dieper sit, wat nooit sal genees nie (269). Juis daarom moet diegene wat met hierdie slagoffers werk, dit met soveel oordeel doen, mag jy nooit valse hoop vir hulle gee nie. Hulle is al deur soveel pyn, dat dit hulle heeltemal sal breek as jy hulle iets belowe wat jy nie kan hou nie (273).

Die woord slaafs het ook ander betekenisse in hierdie verhaal. Dis ook die verhaal van menige polisieoffisier wat onder moeilike omstandighede soos slawe moet werk. Dikwels is die polisiestasie karig toegerus (25) maar steeds kry die manne in uniform die werk gedaan. Nie almal word bevoordeel deur regstellende aksie nie (24) soos Julies wat een van die eerste bruin polisiemanne is wat tot kolonel bevorder is en dit dubbel en dwars verdien het. Maar ook hulle "raak gatvol van die eise wat elke dag" aan hulle gestel word (61).

Te laat besef begaafde polisieoffisiere hoe broos die lewe eintlik is en hoe vining dit weggevat kan word. Dat pistole nie altyd jou veiligheid kan waarborg nie. Die geharde polisieman slaag daarin om een van die grootste misdade van ons tyd op te los. Hy kon egter nie sy huwelik red nie. Blackie se woorde aan Nicci is dus baie betekenisvol in die konteks van hierdie verhaal: "Moenie wag tot jou verhouding ook aan flarde is nie" (292).

Uiteindelik eis hierdie lewe ook sy tol: Blackie se vrou Nina spandeer later meer tyd by haar ouers. Die buurman word later 'n steunpilaar, iemand met wie gepraat kan word as Blackie skurke slaafs najaag.

"Want vir elkeen wat ons toesluit, skiet twee nuwes op" (293).

Uiteindelik begin Nina (en talle ander vroue soos sy) 'n lewe sonder hom (71) en al wat oorbly, is 'n verbitterde poliesman (72).

\section{Michael le Cordeur}

Departement Kurrikulumstudies

Universiteit Stelenbosch

E-pos: mlecorde@sun.ac.za 